\title{
OCCURRENCE OF THE BLACK LACE-WEAVER SPIDER, AMAUROBIUS FEROX, IN CAVES
}

\author{
POJAVLJANJE PAJKA AMAUROBIUS FEROX \\ V JAMAH
}

Enrico LUNGHI ${ }^{1,2, *}$

\begin{abstract}
UDC 595.44:551.435.84

Enrico Lunghi; Occurrence of the Black lace-weaver spider, Amaurobius ferox, in caves

Subterranean habitats house a wide range of species which show a number of adaptations to prevailing ecological conditions. Spiders are among the most abundant predators in caves; however, most studies on cave spiders focus on species adapted to these habitats. This is the first study related to the occurrence of the Black lace-weaver spider, Amaurobius ferox, in caves. The species lacks adaptations to the subterranean habitats and has been observed within meters from the cave entrance all year round, except in late winter until early spring. Furthermore, its occupancy is positively related to the presence of other three cave-dwelling spiders: Metellina merianae, Meta menardi and Tegenaria sp.
\end{abstract}

Key words: Arachnids, biospeleology, Italy, occupancy, subterranean habitat.
Izvleček

UDK 595.44:551.435.84

Enrico Lunghi: Pojavljanje pajka Amaurobius ferox $v$ jamah $\mathrm{V}$ različnih podzemnih habitatih živijo številne živalske vrste, ki so bolj ali manj prilagojene na razmere tamkajšnjega okolja. $\mathrm{V}$ jamah so pajki med najštevilčnejšimi plenilci, a večina študij je omejenih na tiste vrste, ki so že izrazito prilagojene na podzemlje. Pajek Amaurobius ferox ne sodi mednje, v študiji pa je obravnavano njegovo pojavljanje vzdolž jam. Ta površinska vrsta se pojavlja le v vhodih delih jam v vseh letnih časih, $\mathrm{z}$ izjemo pozne zime do začetka pomladi. Njeno pojavljanje $\mathrm{v}$ teh delih je povezano s prisotnostjo treh $\mathrm{v}$ jamah prebivajočih vrst, in sicer pajkov Metellina merianae, Meta menardi in Tegenaria sp.

Ključne besede: pajkovci, biospeleologija, Italija, zasedenost, podzemni habitat.

${ }^{1}$ Key Laboratory of the Zoological Systematics and Evolution, Institute of Zoology, Chinese Academy of Sciences, Beichen West Road 1, 100101, Beijing, China,

${ }^{2}$ Museo di Storia Naturale dell'Università di Firenze, Sezione di Zoologia "La Specola", Via Romana 17, 50125 Firenze, Italy,

e-mail: enrico.arti@gmail.com

* Corresponding author. 


\section{INTRODUCTION}

Subterranean environments (from the deep karst system to the Milieu Souterrain Superficiel) hold particular ecological conditions which frequently promote specific adaptations in the resident species (Culver \& Pipan 2015; Ficetola et al. 2019; Mammola 2019). These conditions include the constant darkness, high microclimatic stability and food paucity (Culver \& Pipan 2019). The most studied subterranean habitats are caves (i.e., the large voids suitable for human exploration; Mammola 2019); therefore, the majority of studies on subterranean species deals with species found in caves. Cavedwelling species are generally subdivided into three main categories according to their degree of adaptation and the ability to complete their lifecycle in subterranean habitats (Howarth \& Moldovan 2018; Mammola 2019). Troglobionts are obligate cave-species which show strong adaptations to subterranean life, such as depigmentation, anophthalmia and elongation of appendages; they can only reproduce successfully in subterranean habitats. Troglophiles are facultative cave-dwelling species which can successfully reproduce in both hypogean and epigean environments and may show some specific adaptations. Trogloxenes are occasional visitors in caves and do not reproduce there; they do not show any specific adaptations.

Spiders are among the most abundant predators in caves (Mammola \& Isaia 2017). Numerous studies have been performed on cave spiders in recent years (Novak et al. 2010; Carver et al. 2016; Mammola \& Isaia 2016; Lipovšek et al. 2018). However, these studies largely focus on species dependant on cave habitats and poorly adapted species are frequently overlooked. Non-obligate cave species can play an important role for the entire ecosystem, as they are often major drivers of allochthonous organic matter; e.g., many bats and crickets come back to the caves after foraging outside, and provide valuable organic matter to local communities through their guano, dead bodies or eggs (Ferreira \& Martins 1999; Lavoie et al. 2007). More thorough studies on species previously thought to be accidental occurrences have demonstrated that these species actively select subterranean habitats with specific environmental features (Lunghi et al. 2014, 2017, 2018), making them important to the local ecosystem.

This is the first study related to the occurrence of the Black lace-weaver spider, Amaurobius ferox (Amaurobiidae), in caves (Fig. 1A). This species often occurs within meters from the cave entrance (Mammola et al. 2018) and shows a peculiar behaviour which may work as exaptation to subterranean habitats (Hesselberg et al. 2019a). After the hatching of spiderlings their mother offers herself as food which is an extreme behaviour (known as matriphagy) useful in habitats with limited food availability (Kim \& Horel 1998; Kim 2009). This study contributes to improving the scant knowledge on A. ferox ecology.
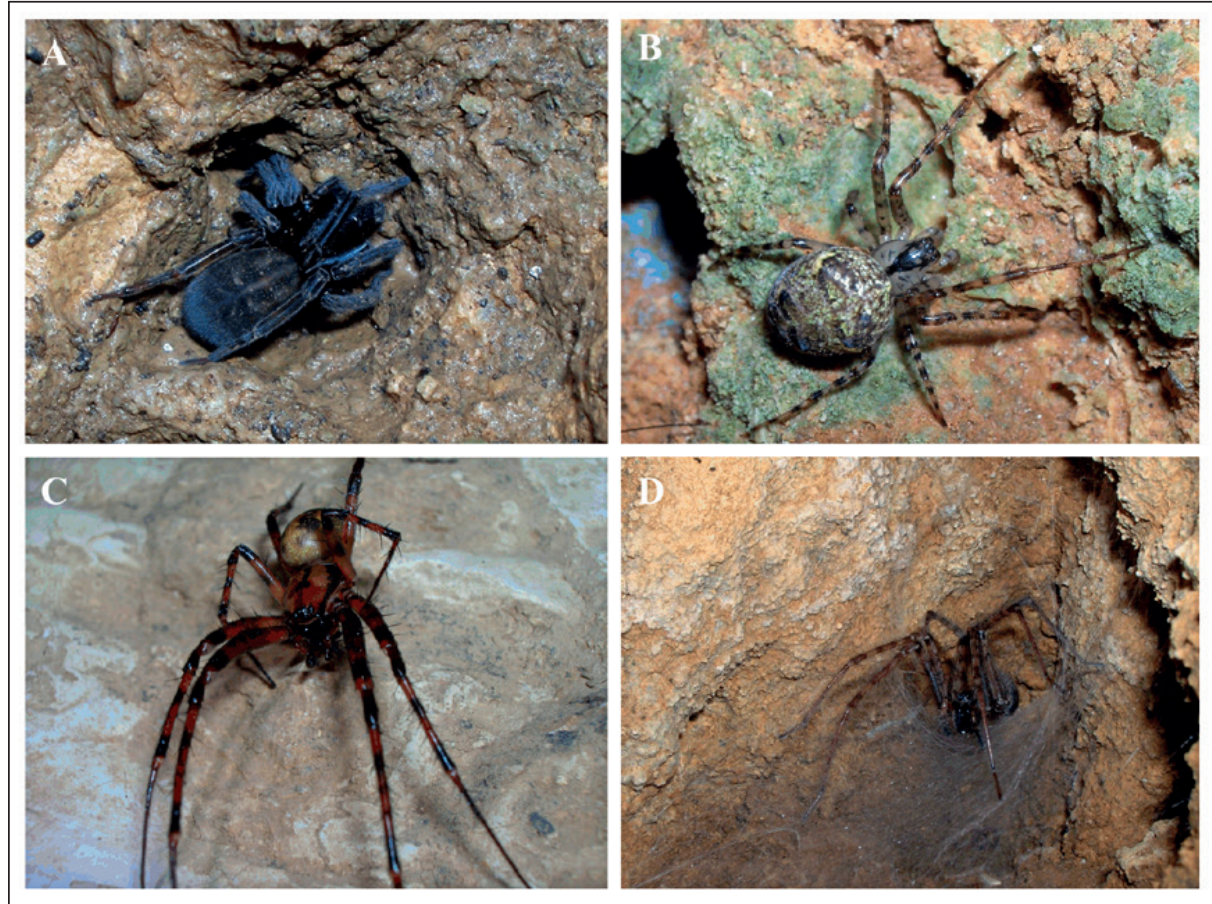

Fig. 1: Amaurobious ferox (A) and the other three cave spiders considered in this study: Metellina merianae (Tetragnathidae) (B); Meta menardi (Tetragnathidae) $(C)$; $c f$. Tegenaria sp. (Agelenidae) (D) (Photo: E. Lunghi). 


\section{METHODS}

\section{DATA COLLECTION}

During the 2013, 16 caves located in the North of Tuscany (Central Italy, between $43^{\circ} 52^{\prime} 42^{\prime \prime} \mathrm{N}, 11^{\circ} 07^{\prime} 18^{\prime \prime} \mathrm{E}$ and $43^{\circ} 59^{\prime} 51^{\prime \prime} \mathrm{N}, 10^{\circ} 13^{\prime} 48^{\prime \prime} \mathrm{E}$; altitudinal range 91-948 $\mathrm{m}$ a.s.l.) were surveyed monthly: this included 12 natural caves, 3 semi-natural caves (i.e., artificially enlarged natural caves) and one drainage tunnel. Surveyed caves were distributed across the Apennines: Apuan Alps (4), Monti della Calvana (8) and Appennino pistoiese (4). Most of the caves were located in forested areas, while two caves and the drainage tunnel were located between forested and urbanized areas. Each cave was surveyed as deep as possible (average explored length around $24 \mathrm{~m}$, range 6-60 m). Starting from the main entrance, the monitored caves were divided into 3-meter long sectors to perform fine-scale data collection (Lunghi et al. 2020). Within each cave sector the following abiotic features were recorded: sector width and height (using a tape meter), average wall irregularity (i.e., presence of protuberances on the cave walls), air temperature $\left({ }^{\circ} \mathrm{C}\right)$ and relative humidity (\%) using a Lafayette TDP92 thermo-hygrometer (accuracy: $0.1{ }^{\circ} \mathrm{C}$ and $0.1 \% \mathrm{RH}$ ) and average illuminance using a Velleman DVM1300 light meter (minimum recordable illuminance: $0.1 \mathrm{~lx}$ ). Wall irregularity was estimated by flattening a one meter string on the cave walls to trace their shape; then, with a tape meter, the linear distance between the two extremities of the string was measured (details in Lunghi et al. 2014). Within each cave sector, the presence and abundance of Amaurobius ferox, on both cave walls and ceiling were assessed by Visual Encounter Survey (VES) (Crump \& Scott 1994) adopting a standardized survey effort of $7.5 \mathrm{~min} / \mathrm{sector}$ to control imperfect species detection (Banks-Leite et al. 2014; Lunghi 2018). For additional information on the dataset and sampling methodology refer to Lunghi et al. (2017).

\section{STATISTICAL ANALYSES}

Data was checked for potential outliers and collinearity between microclimatic covariates prior to analysis (Zuur et al. 2010). The presence of outliers was assessed by plotting the data (boxplots). Relative humidity and illuminance had a series of outliers and thus, to improve the linearity of the data, they were angular-transformed and log-transformed, respectively. Correlation between microclimatic variables was low (pairwise Pearson's $r<0.48$ ), therefore all variables were included in analysis. Generalized Linear Mixed Models (GLMM) assuming binomial error were used to assess the relationship between the occurrence of A. ferox with the environmental features and the occurrence of the three syntopic spider species Metellina merianae, Meta menardi and Tegenaria sp. (Figs. 1B-D) (R packages lme4, MASS, MuMIn; Venables \& Ripley 2002; Douglas et al. 2015; Bartoń 2016; R Development Core Team 2018). These species are regularly found on the cave walls and ceiling in the cave entrance and twilight zones (Mammola \& Isaia 2017; Hesselberg \& Simonsen 2019). The presence/absence of $A$. ferox was used as a dependent variable, while the sector morphological (height, width and wall heterogeneity) and microclimatic features (temperature, humidity and illuminance), along with the presence/absence of the other three syntopic spider species were used as independent variables. As multiple surveys were conducted and the time of survey varied, the month of survey along with the cave and sector identity were used as random factors. Models were built using all possible combinations of the independent variables. Models were then ranked following the Akaike's Information Criterion corrected for small sample size (AICc) (Fang 2011). The model with the lowest AICc value was considered the best; nested models and those representing complex versions with higher AICc values than the simpler were not considered as potential candidates (Richards et al. 2011). The likelihood ratio test was used to assess the significance of variables included in the best AICc model.

\section{RESULTS}

The presence of Amaurobius ferox within cave sectors was assessed 44 times in 10 caves. Only one individual per cave sector was observed; thus, presence data also corresponds to observed abundance. Spiders were observed every month, except in February, March and April, and always within the first 6 cave sectors (up to $18 \mathrm{~m}$ from the cave entrance). The mean ( $\pm \mathrm{SD})$, min and max values of each feature related to the occupied cave sectors were the following: width, $1.27 \pm 1.17(0.76-8.20) \mathrm{m}$, height, $2.20 \pm 0.83(0.60-3.25) \mathrm{m}$, wall irregularity 0.84 \pm 0.12 (0.60-0.98), temperature $14.3 \pm 4.1(4-20.2){ }^{\circ} \mathrm{C}$, humidity $86.5 \pm 5.8(68-95.7) \%$, illuminance $6.5 \pm 11.6$ (0-51.9) lx.

The best AICc model included sector width, temperature, illuminance and the presence of all the three syntopic spider species while the second best model 
Tab. 1: The best five models based on AICc relating the presence of Amaurobius ferox in caves. Its occurrence was considered as dependent variable. Independent variables were: average wall heterogeneity (Het), humidity (Humid), Height and Width of sectors, means of illuminance ( $L x$ ), temperature (Temp), and presencelabsence of Metellina merianae, Meta menardi and Tegenaria sp. Empty cells indicate that the variable is not included into the relative model. Best model is shown in bold.

\begin{tabular}{|c|c|c|c|c|c|c|c|c|c|c|c|c|}
\hline \multicolumn{9}{|c|}{ Independent variables included into the model } & \multirow[t]{2}{*}{ df } & \multirow[t]{2}{*}{ AICc } & \multirow[t]{2}{*}{$\triangle \mathrm{AICc}$} & \multirow[t]{2}{*}{ Weight } \\
\hline Het & Humid & Height & Width & Lx & Temp & M. merianae & M. menardi & Tegenaria & & & & \\
\hline & & & -0.33 & 0.29 & 0.16 & 1.29 & 0.96 & 1.48 & 9 & 278.6 & 0 & 0.082 \\
\hline & & & & 0.29 & 0.15 & 1.30 & 0.97 & 1.52 & 8 & 278.7 & 0.08 & 0.079 \\
\hline & 3.38 & & & 0.32 & 0.19 & 1.28 & 1.01 & 1.60 & 9 & 279.3 & 0.75 & 0.056 \\
\hline & 3.16 & & -0.32 & 0.32 & 0.19 & 1.27 & 0.96 & 1.58 & 10 & 279.4 & 0.84 & 0.054 \\
\hline & & 0.14 & -0.38 & 0.27 & 0.16 & 1.30 & 0.98 & 1.49 & 10 & 280.1 & 1.50 & 0.039 \\
\hline
\end{tabular}

$(\triangle \mathrm{AICc}=0.08)$ included the same variables but not the sector width (Tab. 1).The presence of $A$. ferox was positively related to illuminance $\left(\beta=0.29, \chi^{2}=5.62, P=\right.$ 0.018 ) and to the presence of the three syntopic spider species (Metellina merianae, $\beta=1.29, \chi^{2}=7.73, P=0.005$;
Meta menardi, $\beta=0.96, \chi^{2}=3.86, P=0.05$; Tegenaria sp., $\left.\beta=1.48, \chi^{2}=9.98, P=0.002\right)$; no significant relationship was detected for temperature $\left(\beta=0.16, \chi^{2}=3.51, P=\right.$ $0.061)$ and sector width $\left(\beta=-0.33, \chi^{2}=2.10, P=0.147\right)$.

\section{DISCUSSION}

Amaurobius ferox most likely inhabits caves all year round, selecting specific habitats close to the cave entrance. The lack of species observations during the first part of the year (February-April) may reflect the period in which this spider overwinters inside cave wall crevices. The best model showed that this species mostly inhabits the cave sectors close to the entrance, characterized by higher illuminance and by the presence of all the three syntopic spider species: Metellina merianae, Meta menardi and Tegenaria sp. The difference between the first and the second best model was small $(\triangle \mathrm{AICc}=0.08)$, and showed similar results. The only difference between these two models was the inclusion of sector width in the former model; however, this variable was not significant. The inhabited cave sectors by A. ferox were those close to the cave entrance, where ecological conditions are most similar to those on the surface (Lunghi et al. 2015), and where prey diversity and abundance is higher (Manenti et al. 2015; Lunghi et al. 2017). Considering the lack of specific adaptations to cope with darkness, A. ferox may need to inhabit more illuminated habitats to successfully detect and catch prey using visual cues (Uiblein et al. 1992). Furthermore, higher prey abundance may help females to collect sufficient resources for reproduction, which may not be achieved deeper inside caves (Kim \& Roland 2000; Kim 2009).

Amaurobius ferox tended to occupy cave sectors in which the other syntopic spiders were present. While Metellina merianae and Tegenaria spiders distributions are mostly related to the cave entrance (Lunghi et al. 2017; Hesselberg \& Simonsen 2019), M. menardi is often found also throughout the twilight zone (Lunghi et al. 2017; Hesselberg et al. 2019a). The weak correlation between A. ferox and M. menardi might be attributed to different ecological requirements in these two species, as the latter occupies deeper cave sectors (Mammola \& Isaia 2014; Lunghi et al. 2017; Hesselberg et al. 2019b). The three syntopic cave spiders are better adapted to subterranean habitats and are usually more abundant than $A$. ferox. Further studies are needed to clarify both coexistence and potential competition of these species.

Although limited, observations reported here provide the first information on the use of caves by the spider A. ferox, a spider that regularly inhabits sectors close to the cave entrance. Future studies will strengthen these results and elucidate the importance of this species for the subterranean habitat. 


\section{ACKNOWLEDGEMENTS}

I am thankful to all Reviewers who contributed in improving the first draft of the manuscript. I thank A. C. Hughes for checking the English in the manuscript. The author is supported by the Chinese Academy of Sciences President's International Fellowship Initiative for postdoctoral researchers (grant number 2019PB0143).

\section{RERFERENCES}

Banks-Leite, C., Pardini, R., Boscolo, D., Righetto Cassano, C., Püttker, T., Santos Barros, C. \& J. Barlow, 2014: Assessing the utility of statistical adjustments for imperfect detection in tropical conservation science.- Journal of Applied Ecology, 51, 849-859. https://doi.org/10.1111/1365-2664.12272

Bartoń, K., 2016: MuMIn: Multi-Model Inference. R package version 1.15.6.- [Online] Available from: https://CRAN.R-project.org/package=MuMIn [Accessed October 2019].

Carver, L.M., Perlaky, P., Cressler, A. \& K.S. Zigler, 2016: Reproductive seasonality in Nesticus (Araneae: Nesticidae) cave spiders.- PLoS ONE, 11, e0156751. https://doi.org/10.1371/journal.pone.0156751

Crump, M.L. \& N.J. Scott, 1994: Visual Encounter Surveys.- In: Heyer, W.R. et al. (eds) Measuring and monitoring biological diversity: standard methods for Amphibians. Smithsonian Institution Press, pp. 8492, Washington

Culver, D.C. \& T. Pipan, 2015: Shifting paradigms of the evolution of cave life.- Acta Carsologica, 44, 3, 415425. https://doi.org/10.3986/ac.v44i3.1688

Culver, D.C. \& T. Pipan (eds.), 2019: The biology of caves and other subterranean habitats.- Second edition, Oxford University Press, pp. 336, New York.

Douglas, B., Maechler, M., Bolker, B. \& S. Walker, 2015: Fitting Linear Mixed-Effects Models using lme4.Journal of Statistical Software, 67, 1, 1-48. https:// doi.org/10.18637/jss.v067.i01

Fang, Y., 2011: Asymptotic equivalence between crossvalidations and Akaike Information Criteria in Mixed-Effects Models.- Journal of Data Science 9, $1,15-21$.

Ferreira, R.L. \& R.P. Martins, 1999: Trophic structure and natural history of bat guano invertebrate communities, with special reference to Brazilian caves.- Tropical Zoology, 12, 2, 231-252. https://doi.org/10.1080 /03946975.1999.10539391

Ficetola, G.F., Canedoli, C. \& F. Stoch, 2019: The Racovitzan impediment and the hidden biodiversity of unexplored environments.- Conservation Biology, 33, 1, 214-216. https://doi.org/10.1111/cobi.13179
Hesselberg, T. \& D. Simonsen, 2019: A comparison of morphology and web geometry between hypogean and epigean species of Metellina orb spiders (family Tetragnathidae).- Subterranean Biology, 32, 1-13. https://doi.org/10.3897/subtbiol.32.36222

Hesselberg, T., Simonsen, D. \& C. Juan, 2019a: Do cave orb spiders show unique behavioural adaptations to subterranean life? A review of the evidence.- Behaviour, 156, 10, 969-996. https:/doi. org/10.1163/1568539X-00003564

Hesselberg, T., Simonsen, D. \& C. Juan, 2019b: Unique behavioural adaptations to subterranean life? A review of evidence from cave orb spiders.- Behaviour, 156, 10, 969-996. https://doi. org/10.1163/1568539X-00003564

Howarth, F.G. \& O.T. Moldovan, 2018: The ecological classification of cave animals and their adaptations.In: Moldovan, O.T. et al. (eds) Cave Ecology. Springer, pp. 41-67, Berlin.

Kim, K.W. \& A. Horel, 1998: Matriphagy in the spider Amaurobius ferox (Araneidae, Amaurobiidae): an example of mother-offspring interactions.- Ethology, 104, 12, 1021-1037. https://doi. org/10.1111/j.1439-0310.1998.tb00050.x

Kim, K.W. \& C. Roland, 2000: Trophic egg laying in the spider, Amaurobius ferox: mother-offspring interactions and functional value.- Behavioural Processes, 50, 1, 31-42. https://doi.org/10.1016/S03766357(00)00091-7

Kim, K.W., 2009: Maternal body-mass transfer to offspring in the matriphagous spider, Amaurobius ferox (Amaurobiidae).- Journal of Ecology and Field Biology, 32, 3, 177-182. https://doi.org/10.5141/ JEFB.2009.32.3.177

Lavoie, K.H., Helf, K.L. \& T.L Poulson, 2007: The biology and ecology of North American cave crickets.- Journal of Cave and Karst Studies, 69,1, 114-134.

Lipovšek, S., Novak, T., Janžekovič, F., Brdelak, N. \& G. Leitinger, 2018: Changes in the midgut diverticula epithelial cells of the European cave spider, Meta menardi, under controlled winter starvation.- Sci- 
entific Reports, 8, 13645. https://doi.org/10.1038/ s41598-018-31907-3

Lunghi, E., Manenti, R. \& G.F. Ficetola, 2014: Do cave features affect underground habitat exploitation by non-troglobite species?.- Acta Oecologica, 55, 2935. http://dx.doi.org/10.1016/j.actao.2013.11.003

Lunghi, E., Manenti, R. \& G.F. Ficetola, 2015: Seasonal variation in microhabitat of salamanders: environmental variation or shift of habitat selection?.- PeerJ, 3, e1122. https://doi.org/10.7717/peerj.1122

Lunghi, E., Manenti, R. \& G.F. Ficetola, 2017: Cave features, seasonality and subterranean distribution of non-obligate cave dwellers.- PeerJ, 5, e3169. https:// doi.org/10.7717/peerj.3169

Lunghi, E., 2018: Ecology and life history of Meta bourneti (Araneae: Tetragnathidae) from Monte Albo (Sardinia, Italy).- PeerJ, 6, e6049. https://doi. org/10.7717/peerj.6049

Lunghi, E., Bruni, G., Ficetola, G.F. \& R. Manenti, 2018: Is the Italian stream frog (Rana italica Dubois, 1987) an opportunistic exploiter of cave twilight zone?.- Subterranean Biology, 25, 49-60. https://doi. org/10.3897/subtbiol.25.23803

Lunghi, E., Corti, C., Mulargia, M., Zhao, Y., Manenti, R., Ficetola, G.F. \& M. Veith, 2020: Cave morphology, microclimate and abundance of five cave predators from the Monte Albo (Sardinia, Italy).- Biodiversity Data Journal, 8, e48623. https://doi.org/10.3897/ BDJ.8.e48623

Mammola, S. \& M. Isaia, 2014: Niche differentiation in Meta bourneti and M. menardi (Araneae, Tetragnathidae) with notes on the life history.- International Journal of Speleology, 43, 3, 343-353. http:// dx.doi.org/10.5038/1827-806X.43.3.11

Mammola, S. \& M. Isaia, 2016: The ecological niche of a specialized subterranean spider.- Invertebrate Biology, 135, 1, 20-30. https://doi.org/10.1111/ ivb. 12113

Mammola, S. \& M. Isaia, 2017: Spiders in cave.- Proceedings of the Royal Society B, 284, 20170193. http:// dx.doi.org/10.1098/rspb.2017.0193

Mammola, S., Cardoso, P., Ribera, C., Pavlek, M. \& M
Isaia, 2018: A synthesis on cave-dwelling spiders in Europe.- Journal of Zoological Systematics and Evolutionary Research, 56, 3, 301-316. https://doi. org/10.1111/jzs.12201

Mammola, S., 2019: Finding answers in the dark: caves as models in ecology fifty years after Poulson and White.- Ecography, 42, 7, 1331-1351. https://doi. org/10.1111/ecog.03905

Manenti, R., Lunghi, E. \& G.F. Ficetola, 2015: Distribution of spiders in cave twilight zone depends on microclimatic features and trophic supply.- Invertebrate Biology, 134, 3, 242-251. https://doi. org/10.1111/ivb.12092

Novak, T., Tkavc, T., Kuntner, M., Arnett, A.E., Lipovšek Delakorda, S., Perc, M. \& F. Janžekovič, 2010: Niche partitioning in orbweaving spiders Meta menardi and Metellina merianae (Tetragnathidae).- Acta Oecologica, 36, 6, 522-529. https://doi. org/10.1016/j.actao.2010.07.005

R Development Core Team, 2018: R: A language and environment for statistical computing.- R Foundation for Statistical Computing, Vienna, Austria, [Online] Available from: http://www.R-project.org/. [Accessed $28^{\text {th }}$ September 2018].

Richards, S.A., Whittingham, M.J. \& P.A. Stephens, 2011: Model selection and model averaging in behavioural ecology: the utility of the IT-AIC framework.- Behavioral Ecology and Sociobiology, 65, 1, 77-89. http://dx.doi.org/10.1007/s00265-010-1035-8

Uiblein, F., Durand, J.P., Juberthie, C. \& J. Parzefall, 1992: Predation in caves: the effects of prey immobility and darkness on the foraging behaviour of two salamanders, Euproctus asper and Proteus anguinus.Behavioural Processes, 28, 1-2, 33-40. https://doi. org/10.1016/0376-6357(92)90046-G

Venables, W.N. \& B.D. Ripley, 2002: Modern Applied Statistics with S.- Fourth Edition, Springer, pp. 495, New York.

Zuur, A.F., Ieno, E.N. \& C.S. Elphick, 2010: A protocol for data exploration to avoid common statistical problems.- Methods in Ecology and Evolution, 1, 1, 3-14. https://doi.org/10.1111/j.2041-210X.2009.00001.x 